Article

\title{
Enhancing Sustainability Transparency in Local Governments-An Empirical Research in Europe
}

\author{
Andrés Navarro-Galera, Francisco José Alcaraz-Quiles * and David Ortiz-Rodriguez
}

Department of Accounting and Finance, Faculty of Economics and Business Studies, University of Granada, Campus Universitario de Cartuja, s/n, 18071 Granada, Spain; angalera@ugr.es (A.N.-G.); dortiz@ugr.es (D.O.-R.)

* Correspondence: falcaraz@ugr.es; Tel.: +34-958-249-606

Received: 17 March 2018; Accepted: 21 June 2018; Published: 25 June 2018

\begin{abstract}
In the current socioeconomic context, the question of local government sustainability transparency is of great interest to policymakers, managers, citizens and other stakeholders, and yet one to which previous research has devoted little specific attention. At the same time, the Internet has become an instrument of good governance worldwide and government entities in Europe have strived to promote e-government to improve transparency towards citizens. The aim of this study was to identify factors that can help politicians and managers improve practices of sustainability information disclosed by European local governments. To do so, an empirical study was conducted of 91 municipalities in nine countries, comparing three main administrative cultures. Our analysis of the study results highlights various demographic, socioeconomic, financial and legal factors that may be useful to policymakers and managers in promoting the online provision of sustainability information in Anglo-Saxon, Nordic and Southern European countries.
\end{abstract}

Keywords: sustainability transparency; European local governments; administrative culture

\section{Introduction}

In recent years, the international situation of ongoing financial crisis has led to sustainability being viewed as a key concept in government offices [1,2]. In this regard, international organisations have recommended that governments should adopt governance strategies to implement sustainability criteria in public administration [3-6].

Local governments (LGs) play a key role in the sustainability of public policies. Their proximity to citizens, the volume of resources and services they manage and the high levels of debt and deficit caused by the public financial crisis in many industrialised countries $[7,8]$ make this level of government of particular interest in studies of sustainability, which has economic, social and environmental repercussions for public entities [9-11]. The question of LG activity is also very significant in research into government transparency on sustainability, an issue that is of major interest to many elements of society $[12,13]$.

In recent years, many papers have been published on the question of online transparency by LGs [14-16], and some have considered the question of online disclosure of sustainability information $[12,13,17-19]$, but in most cases only a partial analysis of the situation is presented. In addition, although research findings suggest that cultural differences can affect accountability and transparency [20-22], few studies have been undertaken to address the question of transparency on sustainability from the perspective of the cultural traditions prevailing in different countries [23,24], or to analyse factors that may influence this information disclosure.

Previous research has shown that political and legal differences, as well as administrative culture, can influence the management of public entities $[25,26]$. It has also been reported that the disclosure of non-financial information may vary according to the LG context [27]. The European Union has 
made important advances in the promotion and diffusion of socially responsible policies [28,29], and has emphasised the importance of sustainability in the viability of LGs [30]. In response, many policymakers are working to improve the disclosure of information about sustainability in public entities [18] and some countries have enacted legislation in this regard [24,29]. Public managers may be interested to know the factors that most influence disclosure about sustainability in different administrative cultures because this information would help them design measures to improve their management and communication of sustainability. Therefore, we believe it of interest to determine the level of information disclosed about sustainability by European LGs and the differences in this respect between countries, so that measures can be taken to facilitate the provision of this type of information.

Accordingly, the aim of this paper was to extend our understanding of sustainability transparency in European LGs, in different cultural contexts, and thus contribute to extending this transparency. To do so, we conducted an empirical study of 91 municipalities (in countries with an Anglo-Saxon, Nordic or Southern European administrative culture) to identify factors that impact on online information disclosure. We believe our findings will be useful for policymakers and managers interested in the development of instruments and strategies to enhance transparency about sustainability in the public sector.

\section{Sustainability Transparency and Administrative Cultures}

The outbreak of the financial and economic crisis in 2008 provoked budget cuts in the public sector and, simultaneously, increased the demand for public services, thus heightening the need for good governance [31]. In addition, public authorities have had to respond to increasing demands for information, as citizens seek to participate more actively in public affairs [32].

In this socioeconomic context, the concepts of accountability and transparency, traditionally viewed as crucial elements underpinning the public sector [33], become even more relevant to good governance. Changes towards greater openness can be explained by reference to various theoretical approaches. According to Agency Theory, making more information available facilitates control by citizens (the principal) of the actions of managers and politicians (the agent) [34]. Thus, citizens will act as "armchair auditors", engaged in the political process, promoting accountability and helping prevent corruption [35]. However, most authors have used Legitimacy Theory and/or Stakeholder Theory to explain the need for greater information disclosure [36]. According to these theories, from the citizens' standpoint, the information disclosed by government bodies should take into account the expectations, interests and values of stakeholders, and the policies adopted and actions undertaken should be in accordance with the values of society [37].

Until recently, public information disclosure was primarily focused on financial data [37]. However, there is growing interest in the impact of public actions on social and environmental questions [38,39] and international organisations [5,30,40,41] and stakeholders [42] are calling for public entities to provide more information on the sustainability of their actions.

Sustainability, as a key aspect in the public governance of public entities [43], has been defined as maintaining economic, social and environmental benefits over the long term [5]. Thus, public agencies should increase their accountability, reporting their goals and activities in terms of sustainability [44]. In fact, in recent years, public entities have increasingly included environmental and social information in their annual economic reports $[45,46]$.

Several guides to standardise sustainability reporting have been published [47], including those of the Global Reporting Initiative (GRI), which are widely adopted in the preparation of sustainability reports [38,48]. The G3 guide [49] together with its update G4 [50] and a supplement for public entities [51], establishes a comparative framework on economic, social and environmental aspects of the actions taken by the reporting entity [37]. However, although these guides are considered to be a benchmark for sustainability reporting [48], they have also been criticised. Thus, according to one study [52], the GRI guides propose too many indicators and are very general. Nevertheless, the GRI guides are commonly used, and an increasing number of organisations publish their reports on the 
GRI website (database.globalreporting.org). In the public sector, too, growing numbers of agencies are adopting the GRI guidelines [44].

In this paper, on the basis of the GRI indicators, we study the online disclosure of information about sustainability by LGs in nine European countries. Some previous studies have analysed the disclosure of general or financial information on LG websites [16,53]. In recent years, studies of sustainability transparency in public administration and public utilities have also appeared [17-19,54-57] and several papers have analysed the disclosure of sustainability information by LGs. For example, one study [17] described an exploratory analysis of six European cities, while another [58] focused on the annual sustainability reports of four LGs in Australia. Other papers have considered the information available in a single country. Thus, studies have evaluated the online provision of information about large Spanish cities and have examined relevant economic and political factors [13,59,60]. Other studies have analysed the information disclosure on sustainability by 33 Anglo-Saxon and Nordic local governments [21], and that provided by 62 local governments in Anglo-Saxon and Southern European countries, considering the influence of certain socio-economic variables [24]. Finally, a descriptive analysis has been performed of the sustainability information published online by 72 LGs representative of the three main administrative cultures (Anglo-Saxon, Nordic and Southern European) [23].

These papers highlight the interest and timeliness of studying LG sustainability throughout Europe. In this respect, the EU has pioneered and championed the concept of social responsibility, promoting sustainable, socially responsible practices by public bodies among its Member States [28,61]. In response, various European countries have enacted laws requiring their governments to publish sustainability information $[29,62]$. In this context, the type of administrative culture prevailing in a country has been shown to affect accountability and levels of trust in public institutions [22]. Therefore, it could be very useful to study the influence of this factor on sustainability transparency in specific countries and cultural contexts.

In Europe, various types of administrative culture can be distinguished [36,63], and it has been shown that cultural differences affect the assessment of efficiency and how municipal services are managed [20]. The Anglo-Saxon administrative culture, based on the common law tradition, is characterised as being proactive and consensus-based, with management mechanisms adapted from the private sector, decentralised public services and an emphasis on accountability and efficiency [64]. The Southern European culture presents almost diametrically opposite characteristics. Based on a positive law tradition, public administration tends to be hierarchical and bureaucratic, relying on administrative law, in which the central government sets the general rules for the provision of public services, collects most tax revenues, maintains territorial delegations and places less emphasis on government accountability [21]. The Nordic administrative culture is located in an intermediate position, characterised by the existence of a welfare state and taking particular interest in issues related to social responsibility [61].

Studies have examined the disclosure of specific areas of financial information $[15,20,65]$, but very few have addressed the question of transparency regarding sustainability [23]. For this reason, it would be valuable and timely to further our understanding of the influence of administrative culture on sustainability transparency [21,24].

In view of the above considerations, we analysed the online provision of sustainability information by 91 LGs in Great Britain and Ireland (Anglo-Saxon administrative tradition); Spain and Portugal (Southern European); and Finland, Sweden, Norway, Denmark and the Netherlands (Nordic). From a comparative perspective, our empirical study highlights similarities and differences in practices of information disclosure between these three administrative cultures and identifies factors that impact on online information disclosure. 


\section{Sample Selection and Research Methodology}

\subsection{Sample Selection}

Large LGs were selected for this study for several reasons. First, in the 21st century, this level of government plays a vital role, addressing complex economic and social issues and located at the hub of an expanding telecommunications infrastructure, in a context in which technological, social, environmental and economic challenges must be faced [66]. Furthermore, the majority of the world's population now live in cities, and by 2030 urban areas will be home to two-thirds of the global population [67]. In addition, due to their proximity to citizens, LGs are ideally located for us to study the impact of their sustainability-related actions [13]. Previous studies have reported that LGs play a crucial role in establishing and implementing sustainability policies, creating structures facilitating decision-making processes and projects and promoting transparency [42,68]. In addition, the role of the Internet as a powerful channel of communication for governments, enabling them to provide increased transparency, is especially significant in the local context, for the same reasons of proximity $[68,69]$. Finally, researchers have acknowledged the need for specific analysis of the online sustainability transparency provided by LGs [28]. In this respect, too, the EU Fiscal Sustainability Report [30] underlines the EU's concern about the evolution of local finances, due to the excessive weight of public debt on LG revenues.

Several advantages are gained from analysing larger municipalities rather than small ones, as regards the provision of public services. Firstly, larger municipalities can benefit from economies of scale. Secondly, they are legally required to provide certain public services. Finally, due to stricter information disclosure requirements and the lower relative cost of implementation, large LGs are usually more innovative in the adoption of new technologies $[15,60,70]$.

The EU plays an active role in the promotion and development of public policies on sustainability [28], and one consequence of this is the promulgation of laws compelling public entities to publish sustainability information $[29,69]$.

The public sector in Europe features diverse administrative cultures, and this diversity is relevant to the degree of transparency provided [17,71]. Studies have revealed differences between these cultures and in the degree of involvement by LGs with their citizens, which could affect the provision of public services, the disclosure of information and the degree of adoption of new technologies [20]. Indeed, it has been observed that the legal system applied in a country, especially with respect to transparency, is an excellent indicator of the administrative transparency presented in that country [62,72].

In some previous studies of transparency about sustainability, the study sample is composed of LGs within a single country [59,73], while, in others, two different administrative cultures are represented [21,24]. Another limitation observed in previous research is that the issue has been presented in a purely descriptive manner, without considering the possible influence of other factors [23]. The present study extends these earlier approaches by examining LGs representing the three prevalent administrative cultures in Europe [23,74], and by analysing the possible influence of different factors, including those referring to the legal system, which have not previously been used in this type of analysis.

This study, therefore, considered the impact of transparency laws in Europe, taking into account possible differences among countries arising from their differing administrative cultures. To do so, we examined the 91 largest municipalities in nine European countries, representative of the three main administrative cultures that are most strongly differentiated in Europe: 7 of these LGs are in Finland, 5 in Norway, 5 in Sweden, 5 in Denmark, and 7 in the Netherlands (Nordic culture); 3 are in Ireland and 28 in the United Kingdom (Anglo-Saxon culture); and 12 are in Portugal and 19 in Spain (Southern European culture). Table 1 shows the list of 91 LGs selected. 
Table 1. Local governments by country and by administrative culture.

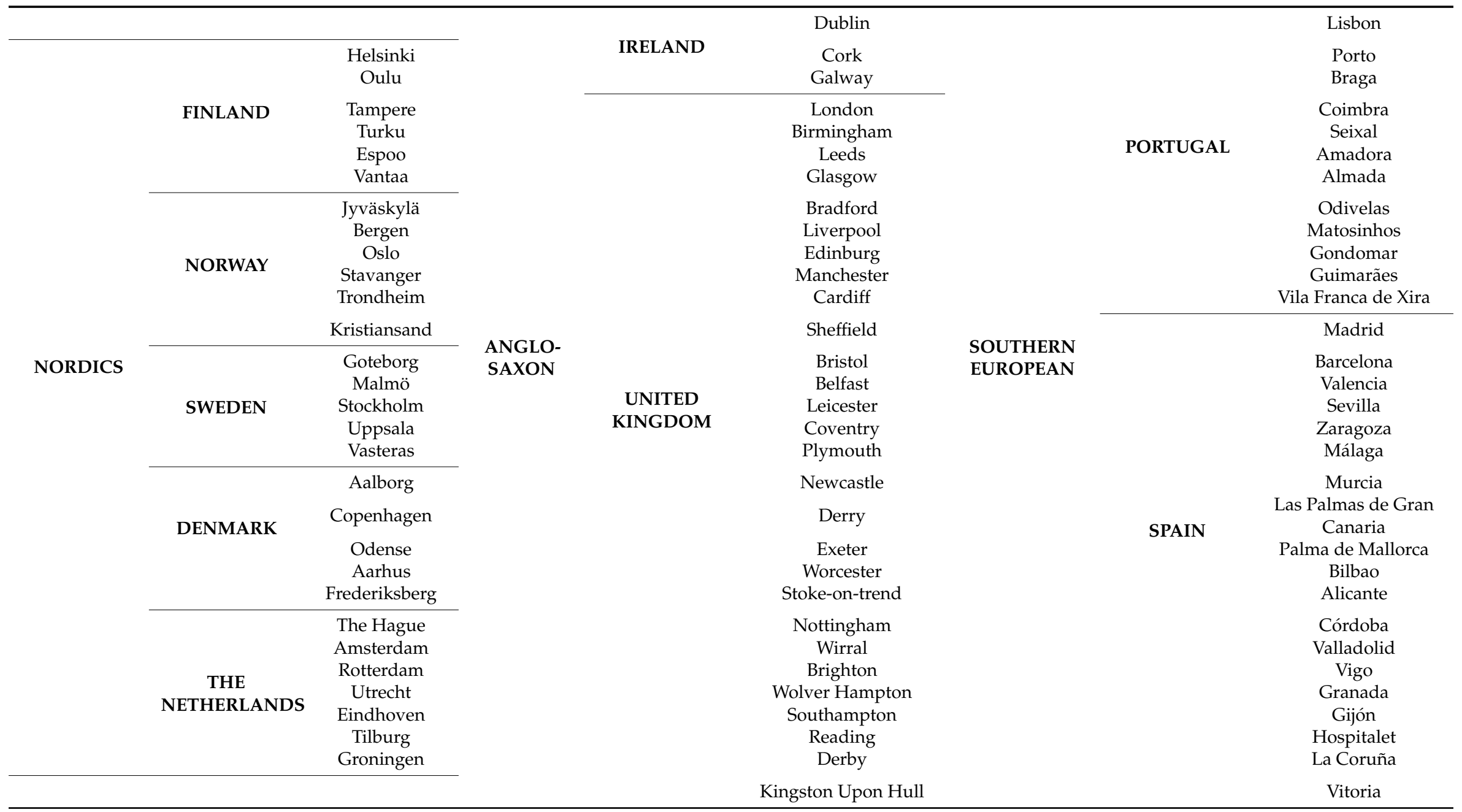




\subsection{Empirical Method}

In recent years, transparency has come to be viewed as a key factor in public sector reforms. The Internet enhances transparency in democratic states by enabling easy, cost-free access to government and policymaking documentation, even if information overload sometimes means it cannot be readily processed [75]. Our study, following the approach adopted in previous work in this field [54,59], examined the websites of 91 LGs to determine their level of online transparency on sustainability.

Considering prior research $[13,18,21,23,24,58,59]$ in this area, we compiled a list of items from the GRI guidelines $[49-51,76]$ to assess the level of LG sustainability information published online. As explained in the previous section, the GRI guidelines are a widely-accepted framework for sustainability reports, and also provide guidance on how they should be related to broader public policy. Despite criticisms of the high number of indicators recommended, the managerial approach taken and the fact that the same specific weight is assigned to all the items, a growing number of public entities worldwide are using the GRI guidelines [77,78]. At present, therefore, the GRI guidelines constitute the global standard for the voluntary disclosure of information on sustainability [38]. In the present study, we considered a set of indicators consisting of 61 items, drawn exclusively from the GRI guidelines, grouped into four blocks of information: general, economic, social and environmental.

Following the method described in previous research, we examined the websites of the 91 LGs in the study sample, by reference to the list obtained from the GRI guidelines [24,59]. The GRI proposes that the items considered should be selected according to stakeholder engagement to determine which aspects are most relevant. The GRI proposal is based on the whole list of items. However, our own analysis had to consider that public entities have multiple stakeholders, and therefore we evaluated exclusively the information disclosed by LGs. Specifically, we conducted an online search to determine whether the information corresponding to the GRI items was available or not, thus obtaining a general overview of each LG's information disclosure. We then created a content analysis index, using the same 61 items, to assess the level of sustainability information disclosure. The data analysed corresponded to the information available during 2015.

Content analysis groups the variables into operationalised attributes, to derive a quantitative measure of the results. This method provides two significant advantages. First, it enables systematic, objective analysis to quantify the content of qualitative data, via a simple, clear and easily-repeatable procedure [79]. Second, it is a discrete method, which has no influence on the analysis unit while the assessment is being carried out [80].

In this content analysis, a score of 1 is awarded if a particular item of information is disclosed, and 0 otherwise. This technique provides a numerical indicator of the amount of information published and has been applied in previous studies [81]. We thus obtained, for each LG, a numerical value of the information disclosed. Using the quantity of information disclosed, we calculated the percentage of total information disclosed (Number of items disclosed/61) and the percentage of information disclosed for each of the four blocks (five dependent variables): (i) General (Number of items disclosed/25); (ii) Economic (Number of items disclosed/16); (iii) Social (Number of items disclosed/7); and (iv) Environmental (Number of items disclosed/13).

Moreover, we identified independent factors that could influence the sustainability information disclosed, grouped into four categories (discussed in the next subsection).

A two-stage statistical analysis was then performed. First, to determine whether the administrative culture corresponding to the LG influenced the transparency provided, we conducted a regression analysis, applying binary codes to each culture. The dependent variable used was the transparency index.

In the second stage, multiple linear regression was used to study the effect of certain variables on sustainability transparency. This technique has been used in several previous studies of LG transparency $[21,24,59]$.

Finally, we carried out several tests to evaluate possible problems of multicollinearity and heteroscedasticity. Thus, the variance inflation factors were $<10$ and the Breusch-Pagan and Koenker tests confirmed the null hypothesis, and thus the absence of multicollinearity and heteroscedasticity, in all cases. 


\subsection{Selecting the Independent Variables}

As mentioned above, in accordance with previous research, 16 explanatory factors were selected (Table 2) and grouped into four different categories: population (5), socioeconomic (5), financial (4) and legal (2). The analysis of legal factors is one of the principal advances in this study with respect to previous analysis, together with its Europe-wide scope.

Table 2. Independent variables.

\begin{tabular}{|c|c|c|c|}
\hline & Variable & Definition & Selection \\
\hline \multirow{4}{*}{$\begin{array}{l}\text { Population } \\
\text { Factors }\end{array}$} & Population Size & Total population of the Local Government (LG) & Eurostat website \\
\hline & Dependent Population & $\begin{array}{l}\text { Percentage of population under } 18 \text { and over } 65 \text { divided by total } \\
\text { population of LG }\end{array}$ & Eurostat website \\
\hline & Immigrant Population & $\begin{array}{c}\text { Percentage of immigrant population divided by total } \\
\text { population of LG }\end{array}$ & Eurostat website \\
\hline & Population Density & Total population of LG divided by total area of LG in $\mathrm{km}^{2}$ & Eurostat website \\
\hline \multirow{5}{*}{$\begin{array}{l}\text { Socioeconomic } \\
\text { Factors }\end{array}$} & Political Competition & The government of LG is by majority or in coalition & Website of each LG \\
\hline & Level of Education & Percentage of graduates divided by total population of LG & Eurostat website \\
\hline & Internet Access & $\begin{array}{l}\text { Percentage of inhabitants with broadband divided by total } \\
\text { population of LG }\end{array}$ & Eurostat website \\
\hline & $\begin{array}{l}\text { Average Disposable } \\
\text { Income }\end{array}$ & $\begin{array}{c}\text { Average income of the municipality divided by the average } \\
\text { number of inhabitants }\end{array}$ & Eurostat website \\
\hline & Unemployment Rate & Percentage of population unemployed & Eurostat website \\
\hline \multirow{4}{*}{ Financial Factors } & Budget surplus/deficit & $\begin{array}{c}\text { Difference between total revenue and total expenditure budget } \\
\text { settlement }\end{array}$ & \multirow{2}{*}{$\begin{array}{l}\text { Ministry of Economy } \\
\text { and Finance website } \\
\text { Ministry of Economy } \\
\text { and Finance website }\end{array}$} \\
\hline & Debt per Capita & Total debt divided by total population of LG & \\
\hline & Financial Autonomy & $\begin{array}{l}\text { Total budgeted income, less (current transfers }+ \text { capital } \\
\text { transfers), divided by total budgeted income }\end{array}$ & Website of each LG \\
\hline & Fiscal Pressure & $\begin{array}{l}\text { Sum of direct taxes and indirect taxes divided by total } \\
\text { population of LG }\end{array}$ & $\begin{array}{l}\text { Ministry of Economy } \\
\text { and Finance website }\end{array}$ \\
\hline Legal Factors & $\begin{array}{l}\text { Age of Transparency } \\
\text { Law (ATL) } \\
\text { Judicial Quality of the } \\
\text { Law (JQL) }\end{array}$ & $\begin{array}{l}\text { Years elapsed since Access to Information Law came into effect } \\
\text { Measure of how well the judicial framework suits the provisions } \\
\text { of the Access to Information Law }\end{array}$ & $\begin{array}{l}\text { Centre for Law and } \\
\text { Democracy } \\
\text { Centre for Law and } \\
\text { Democracy }\end{array}$ \\
\hline
\end{tabular}

\subsubsection{Population Factors}

Following previous studies, as determinant factors of LG transparency, we considered the total municipal population, the dependent population aged under 19 years, the dependent population aged over 65 years, the immigrant population and the population density $[13,16,59,82]$. Some authors reported a positive relation between population and transparency [16,82], while others observed no significant association in this respect [83]. Another factor that has been positively related with transparency is the proportion of the dependent population within the total population [59]. According to previous literature, both the size of the dependent population and the total population density are associated with greater transparency [82]. A study of the projection and composition of the local population [84] estimates that changes in the population size of younger inhabitants (aged less than 19 years) and of older ones (aged over 65 years) produce opposite signs. Another study argues that these population groups have different types of social support and health care requirements, and therefore that their needs for sustainability information could also differ [85]. The last factor selected in this respect, i.e. immigrant population $[59,86]$, was not found to be significantly related to transparency by any of the above authors.

In our study, the above factors were included as possible determinants of LG transparency on sustainability, in the view that an understanding of the influence of population factors on transparency could be useful for politicians and managers wishing to determine whether the size and type of population addressed is relevant to transparency on sustainability. In an economic crisis, when public finances are stretched, both the dependent and the immigrant population present specific sustainability information needs and are net consumers of resources.

\subsubsection{Socioeconomic Factors}

The second group of factors considered comprised the following variables: political competition, level of education, Internet access, average disposable income and rate of unemployment. Studies in 
this respect have reported that transparency is positively associated with political competition [87], the level of education among the population [82], Internet access [24] and average disposable income [87]. However, while some authors believe that municipalities with lower levels of transparency present higher rates of unemployment [16,24], others reached the opposite conclusion [82].

Considering the findings of these previous studies, we hypothesised that political competition, level of education, Internet access, average disposable income and the rate of unemployment could influence LG transparency. These factors, therefore, were addressed in this study, in the view that an understanding of the possible influence of socioeconomic factors on transparency could help politicians and managers decide where efforts should be concentrated.

\subsubsection{Financial Factors}

Various financial factors have been shown to be positively associated with transparency, including budget deficit and debt per capita [53], financial autonomy (i.e., levels of external transfers), and fiscal pressure and financial autonomy [16], and therefore were included as potential influences on sustainability transparency. Knowledge in this regard could be useful for politicians and managers to determine financial and budgetary policies and to achieve transparency on sustainability.

\subsubsection{Legal Factors}

Previous studies have concluded that a country's legal system and its legislation on public access to government information play a key role in determining the level of transparency of public bodies [72]. However, very few international comparisons have been made of the relationships observed in different countries between legislation on access to information and the transparency actually supplied [69]. In our study, two indicators were used to measure the relation between transparency and legislation in this respect, based on the ranking published by the Centre for Law and Democracy (CLD) [62]. On the one hand, we considered the number of years elapsed since the enactment of an Access to Information Law (i.e., the lifespan of the legislation) and, on the other, hand the judicial quality of this legislation.

Although all LGs must apply the same national legislation, the level of implementation may be unequal. Moreover, the quality of the law could influence the level of LG transparency. The CLD evaluates the quality of the law according to seven parameters (right to access, scope, requesting procedures, exceptions and refusals, appeals, sanctions and protections, and promotional measures). According to the level achieved for each of these parameters, implementation of the legal requirements would be more or less viable. The higher is the quality of the law, therefore, the greater is the quantity and quality of the information provided on sustainability [24,29].

According to the CLD, the Nordic countries have longer-established laws on access to information and greater legal quality in this respect than the Anglo-Saxon countries, while the Southern European countries have the lowest levels of legal quality and the most recent legislation [62].

As mentioned above, our study is among the first to include legal factors as possible determinants of transparency on sustainability. The above legal factors were included in the view that they might promote sustainability transparency, and therefore would be of interest to managers and policymakers wishing to understand the influence of the lifespan and quality of laws on transparency.

\section{Empirical Results}

\subsection{Descriptive Analysis}

Tables 3 and 4 show the Pearson and Spearman matrix correlations obtained. In both cases, the variables have a low-value linear correlation. The variables Political Competition and Budget Surplus/Deficit were excluded from our analysis because they are dichotomous (value 1 or 0 ) and hence incompatible with the Pearson and Spearman tests. 
Table 3. Pearson matrix.

\begin{tabular}{|c|c|c|c|c|c|c|c|c|c|c|c|c|c|c|}
\hline & PS & $<19$ & $65>$ & IP & PD & LoE & IA & ADI & UR & $\mathrm{DpC}$ & FA & FP & ATL & JQL \\
\hline Ps & 1.000 & & & & & & & & & & & & & \\
\hline$<19$ & $\begin{array}{c}-0.161 \\
0.128339\end{array}$ & 1.000 & & & & & & & & & & & & \\
\hline $65>$ & $\begin{array}{c}-0.197 \\
0.061268\end{array}$ & $\begin{array}{c}-0.389 \\
0.000141\end{array}$ & 1.000 & & & & & & & & & & & \\
\hline IP & $\begin{array}{c}0.060 \\
0.570702\end{array}$ & $\begin{array}{c}-0.112 \\
0.291417\end{array}$ & $\begin{array}{c}0.200 \\
0.057567\end{array}$ & 1.000 & & & & & & & & & & \\
\hline PD & $\begin{array}{c}0.258 * \\
0.013721\end{array}$ & $\begin{array}{l}-0.252 * \\
0.015862\end{array}$ & $\begin{array}{c}0.082 \\
0.442218\end{array}$ & $\begin{array}{c}0.232 * \\
0.026972\end{array}$ & 1.000 & & & & & & PEARSON & & & \\
\hline LoE & $\begin{array}{c}0.788 \\
1.75 \times 10^{-20} \\
\end{array}$ & $\begin{array}{c}-0.041 \\
6.98 \times 10^{-1}\end{array}$ & $\begin{array}{c}-0.210^{*} \\
4.61 \times 10^{-2}\end{array}$ & $\begin{array}{c}-0.100 \\
3.44 \times 10^{-1} \\
\end{array}$ & $\begin{array}{c}0.291 \\
5.10 \times 10^{-3} \\
\end{array}$ & 1.000 & & & & & & & & \\
\hline IA & $\begin{array}{c}0.101 \\
0.341412\end{array}$ & $\begin{array}{c}0.355 \\
0.000552\end{array}$ & $\begin{array}{c}-0.417 \\
0.000039\end{array}$ & $\begin{array}{c}-0.599 \\
0.000000\end{array}$ & $\begin{array}{c}-0.036 \\
0.731800\end{array}$ & $\begin{array}{c}0.266^{*} \\
0.010707\end{array}$ & 1.000 & & & & & & & \\
\hline ADI & $\begin{array}{c}0.008 \\
0.938348\end{array}$ & $\begin{array}{c}0.037 \\
0.727251\end{array}$ & $\begin{array}{c}-0.176 \\
0.096047\end{array}$ & $\begin{array}{c}-0.415 \\
0.000043\end{array}$ & $\begin{array}{c}0.023 \\
0.828648\end{array}$ & $\begin{array}{c}0.129 \\
0.222722\end{array}$ & $\begin{array}{c}0.464 \\
0.000004\end{array}$ & 1.000 & & & & & & \\
\hline UR & $\begin{array}{c}0.015 \\
0.888952 \\
\end{array}$ & $\begin{array}{c}0.260^{*} \\
0.012648 \\
\end{array}$ & $\begin{array}{c}-0.073 \\
0.493189 \\
\end{array}$ & $\begin{array}{c}0.080 \\
0.452476 \\
\end{array}$ & $\begin{array}{c}-0.015 \\
0.890217 \\
\end{array}$ & $\begin{array}{c}-0.056 \\
0.600270 \\
\end{array}$ & $\begin{array}{c}0.026 \\
0.809027 \\
\end{array}$ & $\begin{array}{c}0.109 \\
0.301675 \\
\end{array}$ & 1.000 & & & & & \\
\hline DpC & $\begin{array}{c}-0.120 \\
0.258261\end{array}$ & $\begin{array}{c}0.339 \\
0.001005\end{array}$ & $\begin{array}{l}-0.246^{*} \\
0.018538\end{array}$ & $\begin{array}{c}-0.159 \\
0.131022\end{array}$ & $\begin{array}{l}-0.256^{*} \\
0.014276\end{array}$ & $\begin{array}{c}-0.049 \\
0.646081\end{array}$ & $\begin{array}{c}0.218^{*} \\
0.037557\end{array}$ & $\begin{array}{c}0.288 \\
0.005601\end{array}$ & $\begin{array}{c}0.033 \\
0.758115\end{array}$ & 1.000 & & & & \\
\hline FA & $\begin{array}{c}-0.053 \\
0.619363\end{array}$ & $\begin{array}{c}0.501 \\
0.000000\end{array}$ & $\begin{array}{c}-0.280 \\
0.007151\end{array}$ & $\begin{array}{c}0.299 \\
0.004016\end{array}$ & $\begin{array}{c}-0.069 \\
0.513400\end{array}$ & $\begin{array}{c}-0.033 \\
0.754814\end{array}$ & $\begin{array}{c}0.076 \\
0.472983\end{array}$ & $\begin{array}{c}0.034 \\
0.747416\end{array}$ & $\begin{array}{c}0.227^{*} \\
0.030478\end{array}$ & $\begin{array}{c}0.418 \\
0.000038\end{array}$ & 1.000 & & & \\
\hline FP & $\begin{array}{c}-0.101 \\
0.338746\end{array}$ & $\begin{array}{c}0.218^{*} \\
0.038343\end{array}$ & $\begin{array}{l}-0.266^{*} \\
0.010888\end{array}$ & $\begin{array}{l}-0.229^{*} \\
0.028688\end{array}$ & $\begin{array}{c}-0.100 \\
0.346877\end{array}$ & $\begin{array}{c}-0.001 \\
0.995695\end{array}$ & $\begin{array}{c}0.412 \\
0.000050\end{array}$ & $\begin{array}{c}0.699 \\
0.000000\end{array}$ & $\begin{array}{c}0.166 \\
0.115595\end{array}$ & $\begin{array}{c}0.481 \\
0.000001\end{array}$ & $\begin{array}{c}0.473 \\
0.000002\end{array}$ & 1.000 & & \\
\hline ATL & $\begin{array}{c}-0.036 \\
0.732657\end{array}$ & $\begin{array}{c}0.277 \\
0.007899 \\
\end{array}$ & $\begin{array}{c}0.068 \\
0.519995 \\
\end{array}$ & $\begin{array}{c}-0.076 \\
0.474889 \\
\end{array}$ & $\begin{array}{l}-0.229 * \\
0.029363\end{array}$ & $\begin{array}{c}-0.085 \\
0.422225 \\
\end{array}$ & $\begin{array}{c}0.207^{*} \\
0.048699 \\
\end{array}$ & $\begin{array}{c}0.095 \\
0.370397 \\
\end{array}$ & $\begin{array}{c}0.277 \\
0.007832 \\
\end{array}$ & $\begin{array}{c}0.382 \\
0.000184 \\
\end{array}$ & $\begin{array}{c}0.380 \\
0.000200 \\
\end{array}$ & $\begin{array}{c}0.471 \\
0.000002 \\
\end{array}$ & 1.000 & \\
\hline JQL & $\begin{array}{c}0.076 \\
0.473703\end{array}$ & $\begin{array}{c}0.477 \\
0.000002\end{array}$ & $\begin{array}{c}-0.369 \\
0.000316\end{array}$ & $\begin{array}{c}-0.047 \\
0.659654\end{array}$ & $\begin{array}{c}-0.100 \\
0.344900\end{array}$ & $\begin{array}{c}0.172 \\
0.103094\end{array}$ & $\begin{array}{c}0.426 \\
0.000025\end{array}$ & $\begin{array}{c}-0.132 \\
0.212474\end{array}$ & $\begin{array}{c}0.021 \\
0.841185\end{array}$ & $\begin{array}{c}0.169 \\
0.109971\end{array}$ & $\begin{array}{c}0.515 \\
0.000000\end{array}$ & $\begin{array}{c}0.018 \\
0.865462\end{array}$ & $\begin{array}{c}0.151 \\
0.153294\end{array}$ & 1.000 \\
\hline
\end{tabular}

* Correlation at 0.05 significance. 
Table 4. Spearman matrix.

\begin{tabular}{|c|c|c|c|c|c|c|c|c|c|c|c|c|c|c|}
\hline & PS & $<19$ & $65>$ & IP & PD & LoE & IA & ADI & UR & $\mathrm{DpC}$ & FA & FP & ATL & JQL \\
\hline Ps & 1.000 & & & & & & & & & & & & & \\
\hline$<19$ & $\begin{array}{c}-0.077 \\
0.466487\end{array}$ & 1.000 & & & & & & & & & & & & \\
\hline $65>$ & $\begin{array}{c}-0.168 \\
0.111690\end{array}$ & $\begin{array}{c}-0.380 \\
0.000202\end{array}$ & 1.000 & & & & & & & & & & & \\
\hline IP & $\begin{array}{c}-0.117 \\
0.267709\end{array}$ & $\begin{array}{c}0.209 * \\
0.046431\end{array}$ & $\begin{array}{l}-0.263 * \\
0.011793\end{array}$ & 1.000 & & & & & & & & & & \\
\hline PD & $\begin{array}{c}0.291 \\
0.00512\end{array}$ & $\begin{array}{l}-0.195 \\
0.06408\end{array}$ & $\begin{array}{l}-0.046 \\
0.66218\end{array}$ & $\begin{array}{c}0.371 \\
0.00030\end{array}$ & 1.000 & & & & & SPEARM & N CORRE & ATION R & & \\
\hline LoE & $\begin{array}{c}0.366 \\
0.000354\end{array}$ & $\begin{array}{c}0.196 \\
0.062885\end{array}$ & $\begin{array}{l}-0.218^{*} \\
0.037468\end{array}$ & $\begin{array}{c}-0.160 \\
0.128822\end{array}$ & $\begin{array}{c}0.178 \\
0.090818\end{array}$ & 1.000 & & & & & & & & \\
\hline IA & $\begin{array}{c}0.134 \\
0.204779\end{array}$ & $\begin{array}{c}0.316 \\
0.002273\end{array}$ & $\begin{array}{c}-0.331 \\
0.001371\end{array}$ & $\begin{array}{c}-0.088 \\
0.407196\end{array}$ & $\begin{array}{c}0.001 \\
0.992577\end{array}$ & $\begin{array}{c}0.436 \\
0.000015\end{array}$ & 1.000 & & & & & & & \\
\hline ADI & $\begin{array}{c}0.243 * \\
0.020105\end{array}$ & $\begin{array}{c}0.030 \\
0.775902 \\
\end{array}$ & $\begin{array}{c}-0.197 \\
0.061208\end{array}$ & $\begin{array}{c}-0.475 \\
0.000002 \\
\end{array}$ & $\begin{array}{c}-0.096 \\
0.367179\end{array}$ & $\begin{array}{c}0.314 \\
0.002415\end{array}$ & $\begin{array}{c}0.383 \\
0.000181 \\
\end{array}$ & 1.000 & & & & & & \\
\hline UR & $\begin{array}{c}-0.149 \\
0.159230\end{array}$ & $\begin{array}{c}0.207 * \\
0.049307\end{array}$ & $\begin{array}{c}-0.015 \\
0.891444\end{array}$ & $\begin{array}{c}0.340 \\
0.000979\end{array}$ & $\begin{array}{c}-0.115 \\
0.278288\end{array}$ & $\begin{array}{c}-0.302 \\
0.003641\end{array}$ & $\begin{array}{c}-0.088 \\
0.407307\end{array}$ & $\begin{array}{c}0.002 \\
0.985236\end{array}$ & 1.000 & & & & & \\
\hline DpC & $\begin{array}{l}-0.240 * \\
0.021945\end{array}$ & $\begin{array}{c}0.488 \\
0.000001\end{array}$ & $\begin{array}{c}-0.320 \\
0.002021\end{array}$ & $\begin{array}{c}0.193 \\
0.067403\end{array}$ & $\begin{array}{c}-0.188 \\
0.074872\end{array}$ & $\begin{array}{c}0.148 \\
0.162807\end{array}$ & $\begin{array}{c}0.351 \\
0.000644\end{array}$ & $\begin{array}{c}0.225 * \\
0.031971\end{array}$ & $\begin{array}{c}0.227 \text { * } \\
0.030636\end{array}$ & 1.000 & & & & \\
\hline FA & $\begin{array}{c}-0.177 \\
0.093496\end{array}$ & $\begin{array}{c}0.439 \\
0.000014 \\
\end{array}$ & $\begin{array}{l}-0.263 * \\
0.011781\end{array}$ & $\begin{array}{c}0.404 \\
0.000070 \\
\end{array}$ & $\begin{array}{c}0.035 \\
0.740137 \\
\end{array}$ & $\begin{array}{c}0.105 \\
0.321661\end{array}$ & $\begin{array}{c}0.290 \\
0.005345\end{array}$ & $\begin{array}{c}0.110 \\
0.297648\end{array}$ & $\begin{array}{c}0.268 * \\
0.010112\end{array}$ & $\begin{array}{c}0.578 \\
0.000000\end{array}$ & 1.000 & & & \\
\hline FP & $\begin{array}{c}-0.047 \\
0.655503\end{array}$ & $\begin{array}{c}0.406 \\
0.000066\end{array}$ & $\begin{array}{c}-0.333 \\
0.001258\end{array}$ & $\begin{array}{c}-0.094 \\
0.373673\end{array}$ & $\begin{array}{c}-0.177 \\
0.093172\end{array}$ & $\begin{array}{c}0.273 \\
0.008835\end{array}$ & $\begin{array}{c}0.552 \\
0.000000\end{array}$ & $\begin{array}{c}0.607 \\
0.000000\end{array}$ & $\begin{array}{c}0.156 \\
0.140459\end{array}$ & $\begin{array}{c}0.695 \\
0.000000\end{array}$ & $\begin{array}{c}0.577 \\
0.000000\end{array}$ & 1.000 & & \\
\hline ATL & $\begin{array}{c}-0.323 \\
0.001795\end{array}$ & $\begin{array}{c}0.321 \\
0.001912 \\
\end{array}$ & $\begin{array}{c}-0.050 \\
0.635325\end{array}$ & $\begin{array}{c}0.181 \\
0.085256\end{array}$ & $\begin{array}{c}-0.312 \\
0.002617\end{array}$ & $\begin{array}{c}0.023 \\
0.826893\end{array}$ & $\begin{array}{c}0.197 \\
0.060609\end{array}$ & $\begin{array}{c}0.144 \\
0.174071\end{array}$ & $\begin{array}{c}0.384 \\
0.000169\end{array}$ & $\begin{array}{c}0.671 \\
0.000000\end{array}$ & $\begin{array}{c}0.630 \\
0.000000\end{array}$ & $\begin{array}{c}0.543 \\
0.000000\end{array}$ & 1.000 & \\
\hline JQL & $\begin{array}{c}0.048 \\
0.756796\end{array}$ & $\begin{array}{c}0.495 \\
0.000003\end{array}$ & $\begin{array}{c}-0.401 \\
0.000171\end{array}$ & $\begin{array}{c}0.265^{*} \\
0.007830\end{array}$ & $\begin{array}{c}-0.019 \\
0.867131\end{array}$ & $\begin{array}{c}0.349 \\
0.001056\end{array}$ & $\begin{array}{c}0.34 \\
0.003302\end{array}$ & $\begin{array}{c}-0.028 \\
0.751388\end{array}$ & $\begin{array}{c}-0.080 \\
0.472051\end{array}$ & $\begin{array}{c}0.368 \\
0.001886\end{array}$ & $\begin{array}{c}0.481 \\
0.000002\end{array}$ & $\begin{array}{c}0.274 \\
0.0055555\end{array}$ & $\begin{array}{c}0.160 \\
0.135546\end{array}$ & 1.000 \\
\hline
\end{tabular}


Overall, the 91 LGs in the sample publish information on 53\% of the items listed in the GRI guidelines. The types of information most often divulged belong to Blocks 1 and 3 (general and social information), with $57 \%$ each, followed by Block 2 (economic information) (52\%) and Block 4 (environmental information) (45\%). By countries, LGs from Ireland (70.49\%), Norway (60.29\%) and the Netherlands (57.89\%) disclose the most sustainability information, while Sweden (38.54\%), Denmark $(44.33 \%)$ and Portugal (44.56\%) disclose the least.

Table 5 shows the percentage of information disclosed and the standard deviation values obtained. In general, the dispersion of data is low. Overall, the greatest grouping around the mean is produced by economic and social information (Blocks 2 and 3), while the greatest dispersion is found in environmental information, mainly due to large standard deviations among the Anglo-Saxon LGs and, to a lesser extent, the Southern European and Nordic ones.

Table 5. Information disclosed (ID) by blocks (BL) and standard deviation (SD).

\begin{tabular}{ccccccccccc}
\hline & \multicolumn{2}{c}{ TOTAL } & \multicolumn{2}{c}{ BL 1 } & \multicolumn{2}{c}{ BL 2 } & \multicolumn{2}{c}{ BL 3 } & BL 4 \\
\hline & ID & SD & ID & SD & ID & SD & ID & SD & ID & SD \\
\hline Nordic & $54 \%$ & 3.8529 & $60 \%$ & 5.0707 & $48 \%$ & 2.1553 & $50 \%$ & 2.8855 & $56 \%$ & 8.4024 \\
Anglo-Saxon & $60 \%$ & 4.3169 & $63 \%$ & 5.7994 & $60 \%$ & 2.1545 & $67 \%$ & 2.7255 & $46 \%$ & 13.0638 \\
Southern European & $46 \%$ & 2.7549 & $48 \%$ & 5.0383 & $48 \%$ & 1.8836 & $52 \%$ & 3.3831 & $34 \%$ & 9.5673 \\
Overall & $53 \%$ & 4.0698 & $57 \%$ & 5.4247 & $52 \%$ & 2.1912 & $57 \%$ & 3.2092 & $45 \%$ & 11.0632 \\
\hline
\end{tabular}

In general, if we observe the total information disclosed, the levels of sustainability transparency in the Nordic and Anglo-Saxon LGs are very similar, while, for the Southern European ones, they are lower. By blocks, the Anglo-Saxon LGs disclose most information in every case except environmental information, where they are surpassed by the Nordic LGs (46\% vs. 56\%). The Southern European LGs have the lowest percentages of information disclosure in every block except social information $(52 \%)$, and except in the latter case always disclose less than $50 \%$ of the information items considered. Only in social information do the Southern European LGs fail to occupy the last place, which in this case corresponds to the Nordic LGs ( $50 \%$ vs. $52 \%$ ).

Table 6 shows that Ireland, Norway and United Kingdom present the highest levels of transparency on sustainability, while Denmark, Portugal and Sweden have the lowest levels.

Table 6. Transparency, Human Development Index and Government Effectiveness Index.

\begin{tabular}{cccc}
\hline COUNTRY & $\begin{array}{c}\text { Sustainability } \\
\text { Transparency Index }\end{array}$ & $\begin{array}{c}\text { Human Development Index } \\
\text { (United Nations, 2016) }\end{array}$ & $\begin{array}{c}\text { Government Effectiveness Index } \\
\text { (World Bank Group, 2016) }\end{array}$ \\
\hline Ireland & $70.83 \%$ & 0.923 & 1.35 \\
Norway & $58.80 \%$ & 0.949 & 1.88 \\
United Kingdom & $57.96 \%$ & 0.909 & 1.61 \\
Finland & $49.43 \%$ & 0.895 & 1.84 \\
The Netherlands & $48.43 \%$ & 0.924 & 1.84 \\
Spain & $48.32 \%$ & 0.884 & 0.52 \\
Denmark & $44.40 \%$ & 0.925 & 1.88 \\
Portugal & $42.92 \%$ & 0.843 & 1.22 \\
Sweden & $38.80 \%$ & 0.915 & 1.78 \\
\hline
\end{tabular}

If we compare this ranking with the Human Development Index for each country, it seems that human development exerts some influence on sustainability transparency, since the countries with higher levels of transparency tend to have a higher rate of human development, with the exception of some Nordic countries, whose position in the ranking of human development is above their position in the ranking of sustainability transparency. However, this comparative analysis reveals that, in the countries of our study sample, government effectiveness is not associated with the level of transparency on sustainability. 


\subsection{Statistical Analysis}

\subsubsection{First Regression Analysis}

As explained in Section 3, we performed two regression analyses. In the first one, the dependent variable used was the total (cumulative) disclosure of information, and, as independent variables, the binary coded variables for the individual cultures. The results obtained show that the similarity between LGs belonging to a particular administrative culture is reflected in similar patterns of transparency among the three administrative cultures, and therefore this type of comparative analysis can be useful and relevant for managers and policymakers. Table 7 shows the result of the first regression.

Table 7. Regression with binary coded for cultures.

\begin{tabular}{ccccc}
\hline & Parameter & Estimated Error & Student $\mathbf{t}$ Value & $p$ Value \\
\hline Nordic & 0.5068 & 0.0291 & 17.4242 & 0.0000 \\
Anglo-Saxon & 0.6444 & 0.0291 & 22.1563 & 0.0000 \\
Southern European & 0.5035 & 0.0291 & 17.3119 & 0.0000 \\
\hline
\end{tabular}

$R^{2}$ : 0.9256; $R^{2}$ adjusted: 0.9230 .

\subsubsection{Second Regression Analysis}

In the first regression analysis, considering the 91 LGs as a whole, five regressions were conducted, taking the percentage of information disclosure as the dependent variable in each case. First, all 61 items were taken, as a whole, followed by the percentage of information disclosure for each of the four blocks included in the list of items. Due to the extreme value of the variable Age of Transparency Law (ATL)ATL in the case of Sweden, this variable was windsorised to minimise its impact as an outlier. Table 8 presents the results of all regressions with the parameter and the estimated error (in brackets). We have highlighted the variables with a level of significance of 0.05 .

Our results show that the ATL, i.e., the length of time that legislation in this respect has been in force, is inversely related with the total (cumulative) disclosure of information, for all the information blocks considered. Similarly, debt per inhabitant is positively associated with the disclosure of total (cumulative), general and environmental information. Additionally, the population size is positively related to the disclosure of total (cumulative) and environmental information. Finally, financial autonomy and fiscal pressure are positively related to the disclosure of general and environmental information, respectively. In all cases, the $\mathrm{R}^{2}$ adjusted value obtained is greater than 0.82 . These results provide a global vision of possible influencing factors on sustainability transparency in LGs in three major European administrative cultures.

In a further examination of the data obtained from the first regression analysis, the same regressions were performed, but individually bounded for each administrative culture, i.e., the dependent variables were the percentages of information disclosure for each administrative culture alone: first, the Nordic, then the Anglo-Saxon and finally the Southern European LGs (Tables 9-11).

For the Nordic LGs, the budget surplus, the debt per inhabitant and the judicial quality of the law (JQL) were found to have a positive influence on the total (cumulative) disclosure of information, while the financial autonomy was inversely related to this disclosure. In addition, financial autonomy was inversely related to general and economic information disclosure. The budget surplus/deficit and the JQL were positively associated with the disclosure of economic and social information, respectively. The debt per inhabitant and the fiscal pressure were positively related to the disclosure of environmental information. The $\mathrm{R}^{2}$ value obtained was greater than 0.80 in all these analyses. 
Table 8. Regression with total LGs and variables.

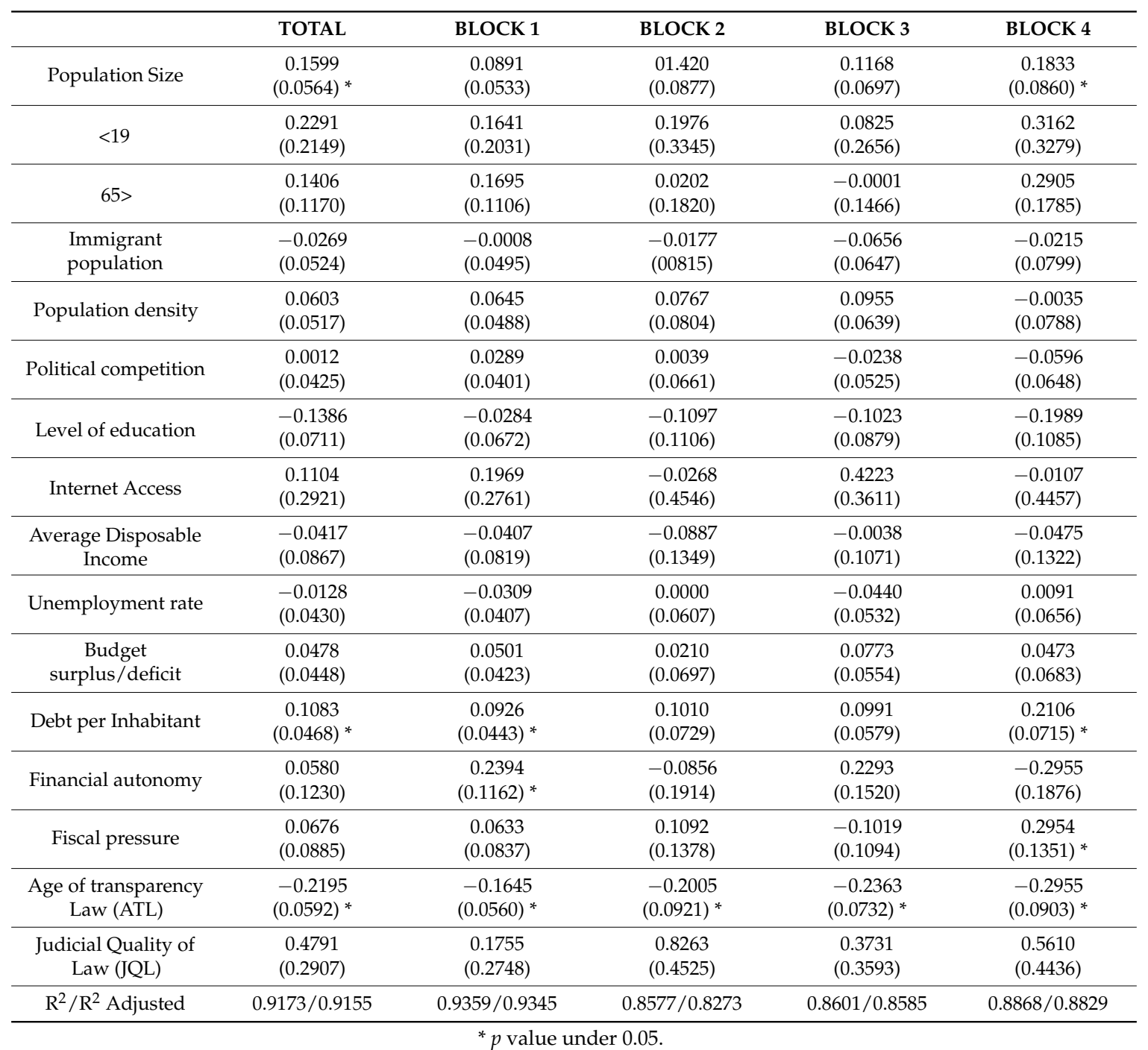

For the Anglo-Saxon LGs, only one factor, i.e. debt per inhabitant, was found to exert a significant influence, being positively associated with environmental information disclosure. The $\mathrm{R}^{2}$ value obtained was higher than 0.87 in this regression.

Contrasting results were obtained from the regression analysis for Southern European LGs. In this case, financial autonomy was positively related to the disclosure of general and environmental information, while political competition and debt per inhabitant were negatively associated with the publication of environmental information. The $\mathrm{R}^{2}$ values obtained ranged from 0.82 to 0.93 .

In short, the factors influencing transparency on sustainability vary according to the administrative culture analysed.

For policymakers and managers seeking to improve governance, these findings contribute a new understanding of the specific influence of population factors on sustainability transparency. Our results show that the total population size exerts a positive influence in this respect, which is in line with the findings of previous authors [16,82]. In contrast to previous results [59], we found that the dependent population has no influence on LG transparency on sustainability. Moreover, while previous studies have found evidence of a positive influence of population density, our own analysis revealed no such relation with sustainability transparency [82]. Finally, corroborating previous studies $[13,16,59,82]$, we found no evidence of any association between the size of the immigrant population and the disclosure of sustainability information. 
Table 9. Regression results by administrative culture: Nordic LGs.

\begin{tabular}{|c|c|c|c|c|c|}
\hline & $\begin{array}{c}\text { TOTAL } \\
\text { Parameter } \\
\text { (Estimated Error) }\end{array}$ & $\begin{array}{c}\text { BLOCK 1 } \\
\text { Parameter } \\
\text { (Estimated Error) }\end{array}$ & $\begin{array}{c}\text { BLOCK 2 } \\
\text { Parameter } \\
\text { (Estimated Error) }\end{array}$ & $\begin{array}{c}\text { BLOCK } 3 \\
\text { Parameter } \\
\text { (Estimated Error) }\end{array}$ & $\begin{array}{c}\text { BLOCK } 4 \\
\text { Parameter } \\
\text { (Estimated Error) }\end{array}$ \\
\hline Population Size & $\begin{array}{c}0.1047 \\
(0.0953)\end{array}$ & $\begin{array}{c}0.0290 \\
(0.1133)\end{array}$ & $\begin{array}{c}0.0489 \\
(0.1932)\end{array}$ & $\begin{array}{c}0.0909 \\
(0.1451)\end{array}$ & $\begin{array}{c}0.2487 \\
(0.1758)\end{array}$ \\
\hline$<19$ & $\begin{array}{c}0.8113 \\
(0.4822)\end{array}$ & $\begin{array}{c}1.1666 \\
(0.5732)\end{array}$ & $\begin{array}{l}1.2510 \\
(0.9770)\end{array}$ & $\begin{array}{c}0.5867 \\
(0.7340)\end{array}$ & $\begin{array}{c}1.2334 \\
(0.8894)\end{array}$ \\
\hline $65>$ & $\begin{array}{l}-0.0949 \\
(0.3872) \\
\end{array}$ & $\begin{array}{l}-0.2602 \\
(0.4603)\end{array}$ & $\begin{array}{l}-1.0521 \\
(0.7845)\end{array}$ & $\begin{array}{l}-0.2354 \\
(0.5894)\end{array}$ & $\begin{array}{c}0.2538 \\
(0.7141) \\
\end{array}$ \\
\hline $\begin{array}{l}\text { Immigrant } \\
\text { population }\end{array}$ & $\begin{array}{c}0.0907 \\
(0.1839)\end{array}$ & $\begin{array}{c}0.0623 \\
(0.2187)\end{array}$ & $\begin{array}{l}-0.1335 \\
(0.3727) \\
\end{array}$ & $\begin{array}{c}0.3942 \\
(0.2800)\end{array}$ & $\begin{array}{c}0.1214 \\
(0.3393)\end{array}$ \\
\hline Population density & $\begin{array}{c}0.0603 \\
(0.1014)\end{array}$ & $\begin{array}{c}0.0813 \\
(0.1205)\end{array}$ & $\begin{array}{c}0.2121 \\
(0.2054)\end{array}$ & $\begin{array}{c}0.1037 \\
(0.1543)\end{array}$ & $\begin{array}{c}0.0165 \\
(0.1870)\end{array}$ \\
\hline Political competition & $\begin{array}{l}-0.0356 \\
(0.0570)\end{array}$ & $\begin{array}{l}-0.0112 \\
(0.0678) \\
\end{array}$ & $\begin{array}{l}-0.0520 \\
(0.11569 \\
\end{array}$ & $\begin{array}{l}-0.1475 \\
(0.0868) \\
\end{array}$ & $\begin{array}{c}0.0334 \\
(0.1052)\end{array}$ \\
\hline Level of education & $\begin{array}{c}0.1687 \\
(0.1725)\end{array}$ & $\begin{array}{c}0.2829 \\
(0.2050)\end{array}$ & $\begin{array}{c}0.4930 \\
(0.34949 \\
\end{array}$ & $\begin{array}{c}0.3469 \\
(0.2625)\end{array}$ & $\begin{array}{c}0.3330 \\
(0.3181)\end{array}$ \\
\hline Internet Access & $\begin{array}{l}-0.4418 \\
(0.7818)\end{array}$ & $\begin{array}{c}0.0264 \\
(0.9295)\end{array}$ & $\begin{array}{c}0.4510 \\
(1.5842)\end{array}$ & $\begin{array}{l}-0.2740 \\
(1.1901)\end{array}$ & $\begin{array}{l}-2.1682 \\
(1.4421)\end{array}$ \\
\hline $\begin{array}{l}\text { Average Disposable } \\
\text { Income }\end{array}$ & $\begin{array}{c}0.0239 \\
(0.2233)\end{array}$ & $\begin{array}{c}0.0697 \\
(0.2655)\end{array}$ & $\begin{array}{c}0.1887 \\
(0.4525)\end{array}$ & $\begin{array}{c}0.0378 \\
(0.3399)\end{array}$ & $\begin{array}{l}-0.1467 \\
(0.4119)\end{array}$ \\
\hline Unemployment rate & $\begin{array}{c}0.0737 \\
(0.1169)\end{array}$ & $\begin{array}{c}0.0656 \\
(0.1390)\end{array}$ & $\begin{array}{c}0.0152 \\
(0.2369) \\
\end{array}$ & $\begin{array}{c}0.0846 \\
(0.1779)\end{array}$ & $\begin{array}{c}0.0463 \\
(0.2156) \\
\end{array}$ \\
\hline $\begin{array}{c}\text { Budget } \\
\text { surplus/deficit }\end{array}$ & $\begin{array}{c}0.2679 \\
(0.1207)^{*}\end{array}$ & $\begin{array}{c}0.1733 \\
(0.1434)\end{array}$ & $\begin{array}{c}0.5473 \\
(0.2445)^{*}\end{array}$ & $\begin{array}{c}0.3406 \\
(0.1837)\end{array}$ & $\begin{array}{c}0.3865 \\
(0.2226)\end{array}$ \\
\hline Debt per Inhabitant & $\begin{array}{c}0.2510 \\
(0.0862) *\end{array}$ & $\begin{array}{c}0.1341 \\
(0.1025)\end{array}$ & $\begin{array}{c}0.3306 \\
(0.1746)\end{array}$ & $\begin{array}{c}0.2336 \\
(0.1312)\end{array}$ & $\begin{array}{c}0.3990 \\
(0.1590)\end{array}$ \\
\hline Financial autonomy & $\begin{array}{l}-1.6787 \\
(0.7397)^{*}\end{array}$ & $\begin{array}{l}-1.9421 \\
(0.8795)^{*}\end{array}$ & $\begin{array}{l}-3.7962 \\
(1.4989)^{*}\end{array}$ & $\begin{array}{l}-2.3507 \\
(1.1261) \\
\end{array}$ & $\begin{array}{l}-1.7571 \\
(1.3645) \\
\end{array}$ \\
\hline Fiscal pressure & $\begin{array}{c}0.3811 \\
(0.2230)\end{array}$ & $\begin{array}{c}0.2978 \\
(0.2652) \\
\end{array}$ & $\begin{array}{c}0.3937 \\
(0.4520)\end{array}$ & $\begin{array}{c}0.1420 \\
(0.3395)\end{array}$ & $\begin{array}{c}0.9969 \\
(0.4114) *\end{array}$ \\
\hline $\begin{array}{l}\text { Age of transparency } \\
\text { Law (ATL) }\end{array}$ & $\begin{array}{l}-0.3254 \\
(0.2061) \\
\end{array}$ & $\begin{array}{l}-0.2032 \\
(0.2451) \\
\end{array}$ & $\begin{array}{c}0.0470 \\
(0.4177)\end{array}$ & $\begin{array}{l}-0.3983 \\
(0.3138) \\
\end{array}$ & $\begin{array}{l}-0.5676 \\
(0.3802)\end{array}$ \\
\hline $\begin{array}{c}\text { Judicial Quality of } \\
\text { Law (JQL) }\end{array}$ & $\begin{array}{c}1.4525 \\
(0.5527) *\end{array}$ & $\begin{array}{c}1.1338 \\
(0.6571)\end{array}$ & $\begin{array}{c}2.2584 \\
(1.1199)\end{array}$ & $\begin{array}{c}2.0587 \\
(0.8414) *\end{array}$ & $\begin{array}{c}1.7649 \\
(1.1095)\end{array}$ \\
\hline $\mathrm{R}^{2} / \mathrm{R}^{2}$ Adjusted & $0.97900 / .9532$ & $0.9704 / 0.9339$ & $0.9139 / 0.8080$ & $0.9514 / 0.8917$ & $0.9287 / 0.8409$ \\
\hline
\end{tabular}

The results of our study provide new knowledge about the influence of these factors on transparency, with particular respect to transparency regarding sustainability in LGs representative of the three main administrative cultures in Europe. According to Legitimacy Theory, policymakers and managers in larger municipalities-those expected to have greater incentives to legitimise their actions-should seek to provide more information on sustainability.

For the socioeconomic factors analysed, our results show that Southern European LGs governed by parties with an absolute majority are the most transparent, a finding that contrasts with previous study results [87]. However, our results are more specific, reporting evidence of the effect on sustainability information. Finally, contrary to previous research findings concerning financial transparency $[16,82,87]$, we obtained no evidence of any influence of Internet access, the rate of unemployment, average disposable income or level of education on this parameter.

The results obtained from the present study contribute to our understanding of transparency in the framework of good governance, confirming the existence of relations between the factors analysed and sustainability transparency within the three main administrative cultures in Europe. These results could be of practical use to managers and policymakers. In the case of southern European LGs, from 
the perspective of Legitimacy Theory, policymakers and managers of cities where the governing party has a clear majority have the support of their citizens regarding the provision of transparency.

Table 10. Regression results by administrative culture: Anglo-Saxon LGs.

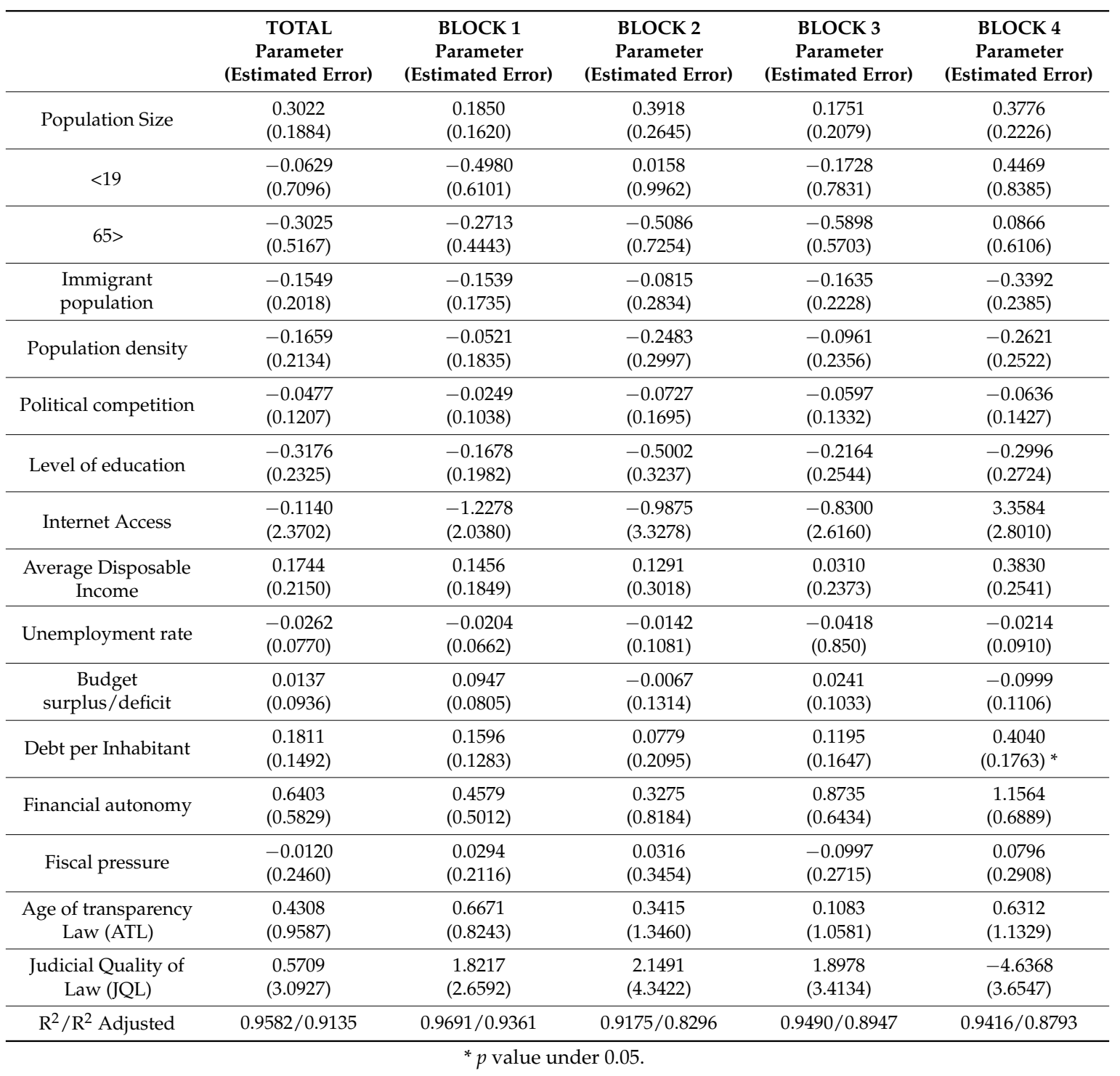

The results of our analysis of financial factors are consistent with previous studies in this respect. Thus, debt per inhabitant is positively associated with transparency on sustainability in all LGs except those in countries with a Southern European administrative culture [53]. For the latter, we recorded an inverse relation between debt per inhabitant on sustainability transparency. These findings are in line with previous research, confirming the positive influence of financial autonomy in Southern European LGs and the negative influence of this parameter in Nordic ones [16]. Additionally, in the Nordic LGs, the budget surplus/deficit and the fiscal pressure were found to exert a positive influence on sustainability transparency, as reported previously [16,53]. All four financial factors examined were associated with transparency. The fact that the financial factors did not appear to influence the economic information provided about sustainability could be due to decreasing preoccupation about the financial future of LGs, as citizens become more financially independent and have greater confidence in their central government.

These findings contribute to our understanding of the question, providing evidence of the relation between these factors and online transparency on sustainability, and reflect the importance of 
administrative culture in this area. From the standpoint of Stakeholder Theory, dependence on external revenue sources and high levels of debt per capita could encourage LGs, especially in countries with Nordic or Anglo-Saxon administrative cultures, to be more transparent. According to Legitimacy Theory, Southern European LGs could become more transparent as municipal debt decreases and when there is reduced dependence on external funding, i.e., according to considerations underlying the ambitions of managers and policymakers to ensure their own legitimacy. Finally, in accordance with Agency Theory, Nordic LGs that present balanced budgets and whose citizens enjoy favourable financial conditions are more likely to disclose information on sustainability, thus defending the common interests of financial security and transparency. Therefore, the existence of a budget surplus could encourage managers and policymakers to expand municipal information disclosure.

Table 11. Regression results by administrative culture: Southern European LGs.

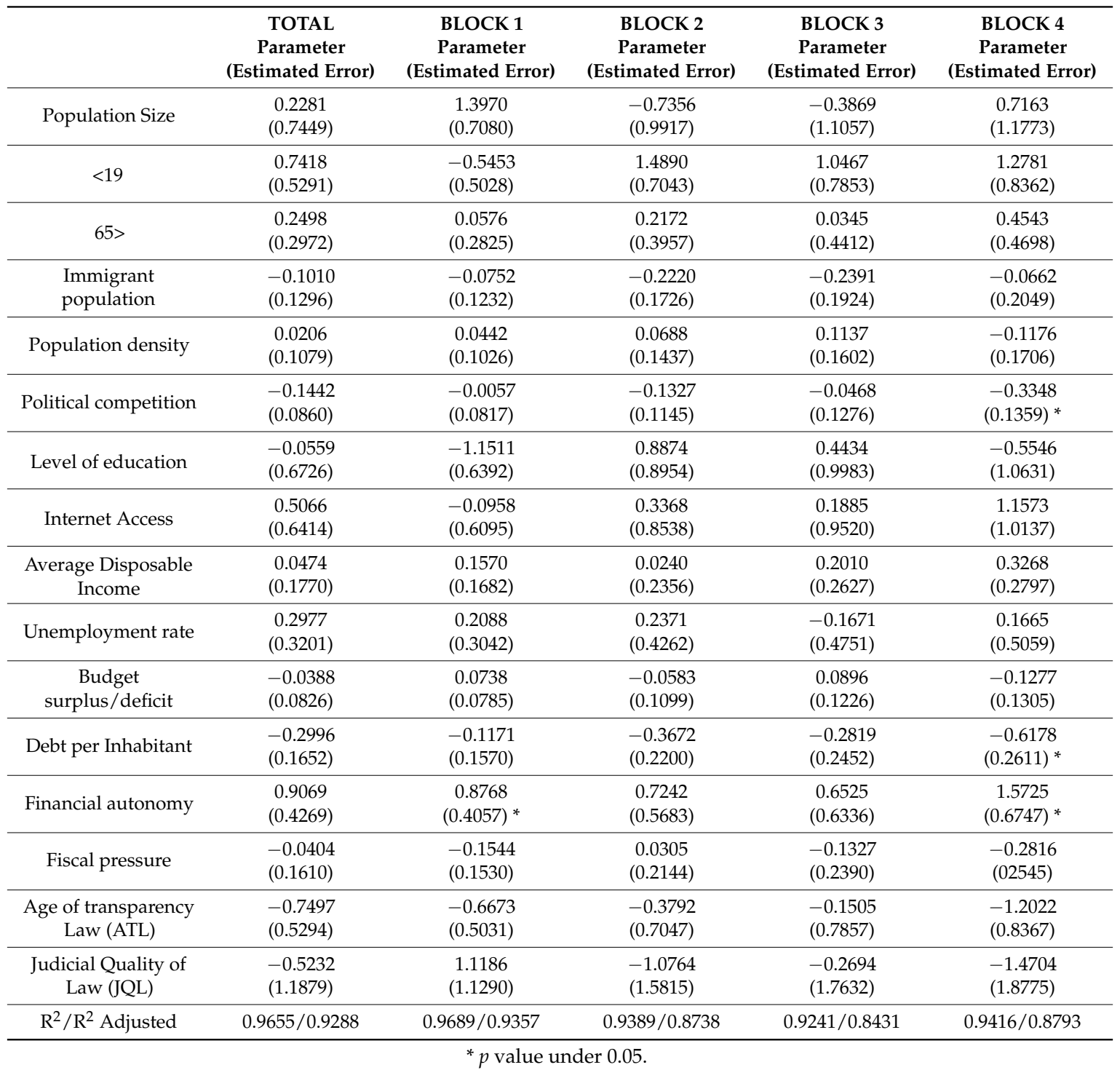

As an innovation in this field of research, we included legal factors in our analysis as possible explanatory factors of transparency on sustainability, considering that previous studies have observed that differences in national legal systems can be an excellent indicator of the openness and transparency of a country's administrative system. Our results show that the age of the transparency legislation and its judicial quality (the latter only in the case of the Nordic LGs) may influence information transparency, particularly that concerning governmental sustainability [72]. The novel aspect of these 
results is that they establish a relationship between the age of transparency legislation and its quality, on the one hand, and the level of online sustainability transparency presented by LGs representative of three administrative cultures, on the other hand. Accordingly, politicians and managers would achieve greater transparency on sustainability if the transparency laws in their countries were updated and their quality improved.

In short, our results provide significant advances on those presented in previous research into the disclosure of sustainability information by LGs $[13,18,21,24,59]$, firstly by the inclusion of legal variables as possible influencing factors, secondly by examining the question of transparency on sustainability in LGs belonging to three major administrative cultures in Europe, and thirdly by addressing factors that could promote this kind of transparency.

\section{Conclusions}

In the view that online transparency is an essential element of public governance, our empirical study was conducted to generate new knowledge that we believe will be useful for politicians and managers seeking to enhance online transparency on sustainability. Our findings represent an advance on the conclusions of previous research in this field. The present study was based on an analysis of 91 LGs in nine European countries, while the scope of previous papers has mainly been limited to a single country. In addition, our empirical results highlight important differences between factors relevant to transparency on sustainability in the three main administrative cultures in Europe. Previous studies have only analysed levels of transparency, without considering possible differences among these three administrative cultures. Finally, our methodological focus addresses more variables than have been considered in previous work. Our principal innovation in this respect is the inclusion of legal factors.

The results obtained in our study show that the LGs in the study sample publish slightly over $50 \%$ of the items recommended by the GRI guidelines for sustainability reporting, with more emphasis on social and general information than on economic and environmental data. By administrative cultures, the largest volume of information is provided by the Anglo-Saxon LGs, followed closely by the Nordic ones, while the Southern European LGs disclose much less information. While the Anglo-Saxon and Southern European LGs show a greater commitment to transparency in areas of social sustainability, the Nordic LGs focus more strongly on general sustainability information.

We conclude, therefore, that policymakers and managers interested in promoting the online provision of information on sustainability have considerable potential for improvement, especially in the Southern European countries. Their efforts should be aimed, primarily, at the types of information currently presenting lower levels of transparency, i.e., environmental information in the Anglo-Saxon and Southern European countries and economic information in the Nordic ones.

The results of our first regression analysis show that the administrative culture of a country is a key determinant of LG commitment to transparency on sustainability. This information is significant for policymakers, especially at the supranational level, who should realise that the measures adopted to promote sustainability need to be differentiated according to the prevailing administrative culture, as there are varying sensitivities to the variables in question. Our analysis gives rise to the following specific conclusions. First, the selection of instruments with which to enhance transparency (such as legal regulations, financial incentives, penalties for deficiencies or measures to foster the demand for information) should be based on different criteria depending on the country in which they are to be applied. Second, the effectiveness of these instruments may also differ significantly depending on the administrative tradition of the country in question, which affects citizens' participation in public affairs and its legal regulation. Accordingly, national and supranational governments should adopt measures suited to the particular characteristics of the target country.

Consideration of the LGs in our study sample reveals the significant influence on the online publication of information about sustainability of three factors in particular. The age of the transparency 
law exerts a negative influence in this respect, while the population size and the debt per inhabitant are positively associated with transparency.

The first of these results could be interpreted in terms of Agency Theory, i.e., the modernisation of laws facilitating citizens' access to government information specifically contributes to LG sustainability transparency. Consequently, we believe that national and supranational institutions could raise levels of transparency sustainability by means of appropriate legislative amendments.

Although previous studies have reported that higher government debt could promote financial transparency, we also show that the presence of rising levels of debt per inhabitant is positively associated with transparency on sustainability. This result, according to Legitimacy Theory, could mean that information on sustainability is used by LGs to justify their actions in situations of financial difficulty. It could also explain why the existence of greater fiscal pressure affects the publication of environmental information.

The relation observed between total population size and the disclosure of sustainability information corroborates previous results on financial information, according to which larger LGs provide more information. However, from Stakeholder Theory, it could also be concluded that the presence of greater citizen awareness stimulates the publication of more information. Therefore, actions to create citizen awareness of the right to information and of the accountability of public entities would affect the publication of information on sustainability.

From the standpoint of politicians wishing to promote transparency on sustainability, it is essential to note that the determinant variables of this question vary widely from one administrative culture to another. Thus, in Nordic countries, both financial factors (budget surplus/deficit, debt per inhabitant, financial autonomy, and fiscal pressure) and legal factors (judicial quality of the law) have a notable impact on sustainability transparency. On the other hand, only one of the financial factors (debt per inhabitant) has such an effect in the Anglo-Saxon LGs. Finally, we show that socioeconomic factors (political competition) and financial factors (debt per inhabitant and financial autonomy) are relevant in Southern European LGs.

In the Nordic LGs, according to Agency Theory, the publication of data regarding debt per capita, financial autonomy and budget result could increase local managers' interest in the provision of sustainability information. Therefore, it would be useful to provide incentives according to the level of sustainability achieved, or to reward the disclosure of information on the sustainability of services. Internal communication campaigns on the financial situation could also be carried out to make managers aware of the importance of accountability.

In the Anglo-Saxon countries, according to Agency Theory, our results suggest that LG transparency on sustainability could be promoted by encouraging politicians in LGs with lower levels of debt to disclose more sustainability information.

In the Southern European LGs, our results suggest that the application of Legitimacy Theory could facilitate transparency on sustainability by encouraging politicians to enable the provision of relevant information, especially when the governing party has an absolute majority. Finally, in accordance with Agency Theory, more information should be provided on the effects of debt per capita and financial autonomy.

Author Contributions: Introduction, F.J.A.-Q. and D.O.R.; Sample selection, A.N.G; Methodology, D.O.R.; Variables selection, F.J.A.-Q. and D.O.R.; Empirical results, A.N.G., F.J.A.-Q. and D.O.R.; Conclusions, A.N.G. F.J.A.-Q. and D.O.R.; Writing review and editing F.J.A.-Q.

Funding: This research received no external funding.

Acknowledgments: Department of Accounting and Finance, Faculty of Economics and Business Studies, University of Granada

Conflicts of Interest: The authors declare no conflict of interest. 


\section{References}

1. Afonso, A.; Jalles, J.T. Fiscal sustainability: A panel assessment for advanced economies. Appl. Econ. Lett. 2015, 22, 925-929. [CrossRef]

2. Rodríguez-Bolívar, M.P.; Navarro-Galera, A.; Alcaide Muñoz, L. New development: The role of accounting in assessing local government sustainability. Public Money Manag. 2014, 34, 233-236. [CrossRef]

3. European Union (EU). Fiscal Sustainability Report 2012; 2012. Available online: http:/ / ec.europa.eu/economy_ finance/publications/european_economy/2012/pdf/ee-2012-8_en.pdf (accessed on 13 January 2018).

4. EU. SGPTD Second Tier Cities and Territorial Development in Europe: Performance, Policies and Prospects; EU: Luxembourg, 2012.

5. International Federation of Accountants (IFAC). Accountability, Sustainability, and Growth Recommendations for the G-20 Leaders' Summit. 2013. Available online: http:/ / www.ifac.org/publications-resources/accountabilitysustainability-and-growth-recommendations-g-20-leaders-summit (accessed on 13 January 2018).

6. IMF. Fiscal Transparency Code; IMF: Washington, DC, USA, 2014.

7. Randma-Liiv, T.; Kickert, W. The Impact of Fiscal Crisis on Public Administration Reforms in Europe. J. Comp. Policy Anal. Res. Pract. 2017, 19, 91-99. [CrossRef]

8. Peters, B.G.; Pierre, J.; Randma-Liiv, T. Global Financial Crisis, Public Administration and Governance: Do New Problems require New Solutions? Public Organ. Rev. 2011, 11, 13-27. [CrossRef]

9. Ebner, D.; Baumgartner, R.J. The relationship between sustainable development and corporate social responsibility. In Proceedings of the Corporate Responsibility Research Conference 2006, Dublin, Ireland, 4-5 September 2006.

10. Opp, S.M.; Saunders, K.L. Pillar talk: Local sustainability initiatives and policies in the United States-finding evidence of the "three E's": Economic development, environmental protection, and social equity. Urban Aff. Rev. 2013, 49, 678-717. [CrossRef]

11. Stazyk, E.C.; Moldavanova, A.; Frederickson, H.G. Sustainability, Intergenerational Social Equity, and the Socially Responsible Organization. Adm. Soc. 2014, 48, 655-682. [CrossRef]

12. Alcaraz-Quiles, F.J.; Navarro-Galera, A.; Ortiz-Rodríguez, D. Factors influencing the transparency of sustainability information in regional governments: An empirical study. J. Clean. Prod. 2014, 82, $179-191$. [CrossRef]

13. García-Sánchez, I.M.; Frías-Aceituno, J.V.; Rodríguez-Domínguez, L. Determinants of corporate social disclosure in Spanish local governments. J. Clean. Prod. 2013, 39, 60-72. [CrossRef]

14. Del Sol, D.A. The institutional, economic and social determinants of local government transparency. J. Econ. Policy Reform 2013, 16, 90-107. [CrossRef]

15. Bonsón, E.; Torres, L.; Royo, S.; Flores, F. Local e-government 2.0: Social media and corporate transparency in municipalities. Gov. Inf. Q. 2012, 29, 123-132. [CrossRef]

16. Guillamón, M.D.; Bastida, F.; Benito, B. The determinants of local government's financial transparency. Local Gov. Stud. 2011, 37, 391-406. [CrossRef]

17. Niemann, L.; Hoppe, T. Sustainability reporting by local governments: A magic tool? Lessons on use and usefulness from European pioneers. Public Manag. Rev. 2017, 20, 201-223. [CrossRef]

18. Brusca, I.; Rossi, F.M.; Aversano, N. Online sustainability information in local governments in an austerity context. Online Inf. Rev. 2016, 40, 497-514. [CrossRef]

19. Alcaraz-Quiles, F.J.; Navarro-Galera, A.; Ortiz-Rodríguez, D. A Comparative Analysis of Transparency in Sustainability Reporting by Local and Regional Governments. Lex Localis J. Local Self-Gov. 2014, 12, 55-78. [CrossRef]

20. Alcaide Muñoz, L.; Rodríguez Bolívar, M.P. Determining Factors of Transparency and Accountability in Local Governments: A Meta-Analytic Study. Lex Localis J. Local Self-Gov. 2015, 13, 129-160. [CrossRef]

21. Navarro Galera, A.; de los Ríos Berjillos, A.; Ruiz Lozano, M.; Tirado Valencia, P. Transparency of sustainability information in local governments: English-speaking and Nordic cross-country analysis. J. Clean. Prod. 2014, 64, 495-504. [CrossRef]

22. Grimmelikhuijsen, S.; Porumbescu, G.; Hong, B.; Im, T. The effect of transparency on trust in government: A cross-national comparative experiment. Public Adm. Rev. 2013, 73, 575-586. [CrossRef] 
23. Navarro Galera, A.; Ruiz Lozano, M.; Tirado Valencia, P.; de los Ríos Berjillos, A. Promoting Sustainability Transparency in European Local Governments: An Empirical Analysis Based on Administrative Cultures. Sustainability 2017, 9, 432. [CrossRef]

24. Ortiz-Rodríguez, D.; Navarro-Galera, A.; Alcaraz-Quiles, F.J. The influence of administrative culture on sustainability transparency in European Local Governments. Adm. Soc. 2018, 50, 555-594. [CrossRef]

25. Haque, M.S. Modernising government: The way forward-An analysis. Int. Rev. Adm. Sci. 2006, 72, 319-325. [CrossRef]

26. Pollit, C.; Bouckaert, G. Public Mangement Reform: A Comparative Analysis; Oxford University Press: Oxford, UK, 2004.

27. Habek, P.; Wolniak, R. Assessing the quality of corporate social responsibility reports: The case of reporting practices in selected European Union member states. Qual. Quant. 2016, 50, 399-420. [CrossRef] [PubMed]

28. Camilleri, M.A. Valuing stakeholder engagement and sustainability reporting. Corp. Reput. Rev. 2015, 18, 210-222. [CrossRef]

29. Reverte, C. The new Spanish corporate social responsibility strategy 2014-2020: A crucial step forward with new challenges ahead. J. Clean. Prod. 2015, 91, 327-336. [CrossRef]

30. EU. Fiscal Sustainability Report. 2014. Available online: http://budgetresponsibility.org.uk/docs/dlm_ uploads/41298-OBR-accessible.pdf (accessed on 22 January 2018).

31. Overmans, J.F.A.; Noordegraaf, M. Managing austerity: Rhetorical and real responses to fiscal stress in local government. Public Money Manag. 2014, 34, 99-106. [CrossRef]

32. Bryson, J.M.; Crosby, B.C.; Bloomberg, L. Public Value Governance: Moving beyond traditional public administration and the New Public Management. Public Adm. Rev. 2014, 74, 445-456. [CrossRef]

33. Lee, J. Preparing performance information in the public sector: An Australian perspective. Financ. Account. Manag. 2008, 24, 117-149. [CrossRef]

34. Gandía, M.C.; Archidona, J.L. Determinants of web site information by Spanish city councils. Online Inf. Rev. 2008, 32, 35-57. [CrossRef]

35. Da Cruz, N.F.; Marques, R.C. Scorecards for sustainable local governments. Cities 2014, 39, $165-170$. [CrossRef]

36. Bellringer, A.; Ball, A.; Craig, R. Reasons for sustainability reporting by New Zealand local governments. Sustain. Account. Manag. Policy J. 2011, 2, 126-138. [CrossRef]

37. Lodhia, S.; Jacobs, K.; Park, Y.J. Driving public sector environmental reporting. Public Manag. Rev. 2012, 14, 631-647. [CrossRef]

38. Hahn, R.; Lülfs, R. Legitimizing negative aspects in GRI-oriented sustainability reporting: A qualitative analysis of corporate disclosure strategies. J. Bus. Ethics 2014, 123, 401-420. [CrossRef]

39. EU. Corporate Social Responsibility: Accountable, Transparent and Responsible Business Behaviour and Sustainable Growth. 2013. Available online: http:/ / www.europarl.europa.eu/oeil/popups / ficheprocedure. do? reference=2012/2098(INI)\&l=EN (accessed on 22 January 2018).

40. G-20. G-20 Leaders' Declaration. Document, St. Petersburg, Russia, 6 September 2013. Available online: www.g20.org (accessed on 22 January 2018).

41. United States Agency for International Development (USAID). Fundamentals of NGO Financial Sustainability; Abt Associates Inc.: Bethesda, MD, USA, 2011.

42. Krause, R.M.; Feiock, R.C.; Hawkins, C.V. The administrative organization of sustainability within local government. J. Public Adm. Res. Theory 2016, 26, 113-127. [CrossRef]

43. Guthrie, J.; Ball, A.; Farneti, F. Advancing sustainable management of public and not for profit organisations. Public Manag. Rev. 2010, 12, 449-459. [CrossRef]

44. Beare, D.; Buslovich, R.; Searcy, C. Linkages between corporate sustainability reporting and public policy. Corp. Soc. Responsib. Environ. Manag. 2014, 21, 336-350. [CrossRef]

45. Erkkila, T. Global governance indices as policy instruments: Actionability, transparency and comparative policy analysis. J. Comp. Policy Anal. 2015, 18, 382-402. [CrossRef]

46. IFAC. Illuminating the Issues Highlighting the Solutions. 2011. Available online: http://viewer.zmags.com/ publication/ed4395af\#/ed4395af/1 (accessed on 10 January 2018).

47. Dumay, J.; Farneti, F.; Guthrie, J. The worth of international guidelines for sustainability reporting in public and not for profit sector organisations. In Proceedings of the Sustainable Management of Organisations Conference, Bologna, Italy, 1-3 July 2009. 
48. KPMG. The KPMG Survey of Corporate Responsibility Reporting 2013. 2013. Available online: http:/ / www.kpmg.com/global/en/issuesandinsights/articlespublications/corporateresponsibility/pages/ corporate-responsibility-reporting-survey-2013.aspx (accessed on 15 January 2018).

49. Global Reporting Initiative (GRI). G3 Sustainability Reporting Guidelines; GRI: Amsterdam, The Netherlands, 2006.

50. GRI. G4 Sustainability Reporting Guidelines. 2013. Available online: https://www.globalreporting.org/ reporting/g4/Pages/default.aspx (accessed on 10 January 2018).

51. GRI. Reporting in Government Agencies; GRI: Amsterdam, The Netherlands, 2010.

52. Smith, N.C.; Lessen, G. Mainstreaming corporate responsibility: An introduction. In Mainstreaming Corporate Responsibility; Smith, N.C., Lessen, G., Eds.; Willey: West Sussex, UK, 2009; pp. 2-8.

53. Caamaño-Alegre, J.; Lago-Peñas, S.; Reyes-Santias, F.; Santiago-Boubeta, A. Budget transparency in local governments: An empirical analysis. Local Gov. Stud. 2013, 39, 182-207. [CrossRef]

54. Navarro-Galera, A.; Alcaraz-Quiles, F.J.; Ortiz-Rodríguez, D. Online dissemination of information on sustainability in Regional Governments. Effects of technological factors. Gov. Inf. Q. 2016, 33, 53-66. [CrossRef]

55. Papenfuß, U.; Grüb, B.; Frieländer, B. Nachhaltigkeitsberichterstattung öffentlicher Unternehmen—Entwicklung eines Qualitätsmodells und empirische Befunde für Stadtwerke im internationalen Vergleich. J. Public Nonprofit Serv. 2015, 38, 170-187.

56. Greiling, D.; Traxler, A.A.; Stötzer, S. Sustainability reporting in the Austrian, German and Swiss public sector. Int. J. Public Sect. Manag. 2015, 28, 404-428. [CrossRef]

57. Lopatta, K.; Jaeschke, R. Sustainability reporting at German and Austrian universities. Int. J. Educ. Econ. Dev. 2014, 5, 66-90. [CrossRef]

58. Goswami, K.; Lodhia, S. Sustainability disclosure patterns of South Australian local councils: A case study. Public Money Manag. 2014, 34, 273-280. [CrossRef]

59. Alcaraz-Quiles, F.J.; Navarro-Galera, A.; Ortiz-Rodríguez, D. Factors determining online sustainability reporting by local governments. Int. Rev. Adm. Sci. 2015, 81, 79-109. [CrossRef]

60. Cuadrado-Ballesteros, B. The impact of functional decentralization and externalization on local government transparency. Gov. Inf. Q. 2014, 31, 265-277. [CrossRef]

61. Midttun, A.; Gjølberg, M.; Kourula, A.; Sweet, S.; Vallentin, S. Public policies for corporate social responsibility in four Nordic countries: Harmony of goals and conflict of means. Bus. Soc. 2015, 54, 464-500. [CrossRef]

62. Centre for Law and Democracy (CDL). Global Right to Information Rating. 2015. Available online: www.rtirating.org (accessed on 15 January 2018).

63. Alam, M.; Nandam, R. Public Sector Reform and Accounting Change in a Cultural Environment. In Proceedings of the 7th ASBBS International Conference, Cairns, Australia; 2004.

64. Gallego-Álvarez, I.; Rodríguez-Domínguez, L.; García-Sánchez, I.M. Are determining factors of municipal E-government common to a worldwide municipal view? An intra-country comparison. Gov. Inf. Q. 2010, 27, 423-430. [CrossRef]

65. Rodríguez-Bolívar, M.P.; Navarro-Galera, A. The Effect of Changes in the Public Sector Accounting Policies on Administrative Reforms Addressed to Citizens. Adm. Soc. 2016, 48, 31-72. [CrossRef]

66. David, N.; Justice, J.; McNutt, J.G. Smart Cities Are Transparent Cities: The Role of Fiscal Transparency in Smart City Governance. In Transforming City Governments for Successful Smart Cities; Rodriguez-Bolivar, M.P., Ed.; Springer International Publishing AG: Basel, Switzerland, 2015; pp. 69-86.

67. United Nation (UN). World Urbanization Prospects; UN: New York, NY, USA, 2014.

68. Shepherd, E.; Stevenson, A.; Flinn, A. Information governance, records management, and freedom of information: A study of local government authorities in England. Gov. Inf. Q. 2010, 27, 337-345. [CrossRef]

69. Relly, J.E.; Sabharwal, M. Perceptions of transparency of government policymaking: A cross-national study. Gov. Inf. Q. 2009, 26, 148-157. [CrossRef]

70. Pérez-López, G.; Prior, D.; Zafra-Gómez, J.L.; Plata-Díaz, A.M. Cost efficiency in municipal solid waste service delivery. Alternative management forms in relation to local population size. Eur. J. Oper. Res. 2016, 255, 583-592. [CrossRef]

71. Navarro Galera, A.; Rodríguez Bolivar, M.P. Modernizing governments in transitional and emerging economies through financial reporting based on international standards. Int. Rev. Adm. Sci. 2011, 77, 609-640. [CrossRef] 
72. La Porte, T.M.; Demchak, C.C.; de Jong, M. Democracy and bureaucracy in the age of the web. Empirical findings and theoretical speculations. Adm. Soc. 2002, 34, 411-446. [CrossRef]

73. Joseph, C.; Taplin, R. The Measurement of Sustainability Disclosure: Abundance versus Occurrence. Account. Forum 2011, 35, 19-31. [CrossRef]

74. Kickert, W. Public Management in the United States and Europe. In Public Management and Administrative Reform in Western Europe; Kickert, W., Ed.; Edward Elgar: Cheltenham, UK, 1997; pp. 15-38.

75. Margetts, H. The Internet and Transparency. Political Q. 2011, 82, 518-521. [CrossRef]

76. GRI. Sector Supplement for Public Agencies; GRI: Amsterdam, The Netherlands, 2005.

77. Wasiluk, K.L. Beyond eco-efficiency: Understanding CS through the IC practice lens. J. Intellect. Cap. 2013, 14, 102-126. [CrossRef]

78. Tort, L.E. GRI Reporting in Government Agencies; GRI: Amsterdam, The Netherlands, 2010.

79. Chu, H. Research methods in library and information science: A content analysis. Libr. Inf. Sci. Res. 2015, 37, 36-41. [CrossRef]

80. Baker, D.L. Advancing E-Government performance in the United States through enhanced usability benchmarks. Gov. Inf. Q. 2009, 26, 82-88. [CrossRef]

81. Melitski, J.; Manoharan, A. Performance measurement, accountability, and transparency of budgets and financial reports. Public Adm. Q. 2014, 38, 38-70.

82. Homsy, G.C.; Warner, M.E. Cities and Sustainability: Polycentric Action and Multilevel Governance. Urban Aff. Rev. 2015, 51, 46-73. [CrossRef]

83. Navarro, A.; Alcaraz, F.J.; Ortiz, D. La Divulgación de Información sobre Responsabilidad Social Corporativa en Administraciones Públicas: Un Estudio Empírico en Gobiernos Locales. Rev. Contabilidad/Span. Account. Rev. 2010, 13, 285-314.

84. Colby, S.L.; Ortman, J.M. Projections of the Size and Composition of the U.S. Population: 2014 to 2060; U. S. Census Bureau: Washintong, DC, USA, 2015.

85. Helliwell, J.F.; Layard, R.; Sachs, J. World Happiness Report 2015; Sustainable Development Solutions Network: New York, NY, USA, 2015.

86. Benito, B.; Bastida, F.; García, J.A. Explaining differences in efficiency: An application to Spanish municipalities. Appl. Econ. 2010, 42, 515-528. [CrossRef]

87. Harrison, T.M.; Sayogo, D.S. Transparency, participation, and accountability practices in open government: A comparative study. Gov. Inf. Q. 2014, 31, 513-525. [CrossRef] 